\title{
ANTONIO DÍEZ QUESADA, PROFESOR EMÉRITO
}

E131 de enero de 2018 se llevó a cabo la ceremonia de nombramiento de profesores eméritos. El ITAM reconoció como profesores eméritos al doctor Carlos Bosch Giral, del Departamento Académico de Matemáticas, al doctor Rodolfo Darío Vázquez Cardozo, del Departamento Académico de Derecho y al maestro Antonio Jesús Díez Quesada, del Departamento Académico de Estudios Generales.

El maestro Díez se distinguió por la calidad y calidez de su labor docente, ejercida durante más de treinta años. Un verdadero humanista de nuestro tiempo, por su preocupación por la persona humana, la amplitud de su cultura y la altura de metas que proponía a sus alumnos, colegas y amigos.

Reproducimos a continuación el discurso laudatorio de la doctora María Julia Sierra y las palabras de agradecimiento del maestro Antonio Díez que se pronunciaron en dicha ceremonia. 